\title{
PENGGUNAAN PENDEKATAN KONTEKSTUAL UNTUK MENINGKATKAN HASIL BELAJAR SISWA PADA MATERI BAGIAN-BAGIAN UTAMA TUBUH HEWAN DAN KEGUNAANNYA DI KELAS II SDN KULUR I KECAMATAN MAJALENGKA KABUPATEN MAJALENGKA
}

Oleh

Dedeh Hapidah

\begin{abstract}
ABSTRAK
Penelitian bertujuan meningkatkan hasil belajar siswa dalam pembelajaran Ilmu Pengetahuan Alam tentang bagian-bagian utama tubuh hewan dan kegunaannya. Desain penelitian ini menggunakan model penelitian Tindakan Kelas yang terdiri dari dua siklus. Setiap siklusnya meliputi tahapan perencanaan, pelaksanaan tindakan, obeservasi dan refleksi. Penelitian ini dilaksanakan di SD Negeri Kulur I, subjek penelitian adalah kelas II berjumlah 26 orang siswa, terdiri atas 14 laki-laki dan 12 orang perempuan. Uji coba pelaksanaan perbaikan pembelajaran dimulai tanggal 23 dan 30 Oktober 2015. Dalam penelitian ini penulis menggunakan metode deskriptif. Metode tersebut digunakan untuk mendeskripsikan pengaruh penggunaan pendekatan pembelajaran kontekstual terhadap hasil belajar siswa di kelas II SD Negeri Kulur I. Hasil penelitian menunjukan bahwa pendekatan pembelajaran kontekstual mampu meningkatkan hasil belajar pada siswa kelas II SD Negeri Kulur I Kecamatan Majalengka Kabupaten Majalengka. Hal itu dikarenakan pendekatan konstektual mampu meningkatkan minat dan hasil evaluasi dalam pembelajaran Ilmu Pengetahuan Alam. Dengan demikian, kesimpulan dari penelitian ini adalah pelaksanaan perbaikan pembelajaran dengan menggunakan pendekatan kontekstual, dapat meningkatkan hasil belajar siswa, minat siswa kelas II SDN Kulur I Kecamatan Majalengka Kabupaten Majalengka setelah mengikuti pembelajaran dengan menggunakan pendekatan kontekstual meningkat secara signifikan dan realistik. Peningkatan hasil belajar tersebut diketahui dari hasil tindakan siklus I dan siklus II. Nilai rata-rata pra siklus sebesar 68,18. Pada siklus I diperoleh nilai rata-rata sebesar 70,96 dan persentase keberhasilan 38,70\% termasuk dalam kategori rendah. Pada tindakan siklus II nilai rata-rata yang dicapai adalah sebesar 81,29 dengan persentase keberhasilan 74,20 \% termasuk dalam kategori tinggi. Dengan melihat data keberhasilan tersebut maka diindikasikan bahwa perbaikan pembelajaran dengan menggunakan pendekatan kontekstual berhasil dengan baik.
\end{abstract}

Kata kunci : Hasil Belajar Siswa, Pendekatan Kontekstual

\footnotetext{
${ }^{1}$ Penulis adalah Guru SD Negeri Kulur I Kecamatan Majalengka
} 


\section{PENDAHULUAN}

Sebagai pengajar guru hendaknya memiliki perencanaan pengajaran yang cukup matang. Perncanaan pengajaran tersebut erat kaitannya dengan berbagai unsur, seperti tujuan pengajaran, bahan pengajaran, kegiatan belajar, metode mengajar, dan evaluasi hasil belajar. Unsurunsur itu merupakan bagian integral dari keseluruhan tanggung jawab guru dalam proses belajar mengajar. Dengan kata lain, guru harus mampu melaksanakan pengelolaan kelas. Karena keberhasilan suatu pembelajaran sangat ditunjang oleh berhasil tidaknya guru dalam pengelolaan kelas. Terutama pengelolaan ketika proses belajar mengajar berlangsung.

Keberhasilan pembelajaran bukanlah semata-mata faktor guru saja namun banyak faktor yang menentukan keberhasilan suatu proses pembelajaran. Namun tidak dapat dipungkiri, guru adalah penanggungjawab perencanaan dan pelaksanaan proses belajar mengajar di sekolah. Sampai saat ini guru masih dominan dalam melaksanakan pembelajaran. Walau berbagai pendekatan dan metode yang menjurus pada siswa aktif seperti CBSA, dan CTL yang sedang trend saat ini, agar siswa menjadi subjek belajar. Pada kenyataannya masih banyak kelemahan yang memerlukan uluran tangan guru.

Berdasarkan kenyataan yang terjadi di lapangan, dewasa ini masih berlangsung bahkan mungkin sudah menjadi suatu kebiasaan dalam menyampaikan proses pembelajaran peran guru masih dominan. Hal ini mungkin disebabkan karena guru masih berpandangan bahwa pengetahuan adalah sebagai perangkat fakta-fakta yang harus dihafalkan oleh peserta didik. Dengan adanya pandangan tersebut mengakibatkan kelas masih berfokus pada guru sebagai sumber pengetahuan, kegiatan belajar mengajar di kelas kurang menggali potensi siswa, metode mengajar kurang bervariasi dan kemudian ceramah menjadi alternative utama dalam strategi belajarnya.
Pada umumnya peserta didik menganggap bahwa Ilmu Pengetahuan Alam (IPA) sebagai suatu pembelajaran yang sukar dan membosankan sebab sebagian besar materi terdiri dari konsep, fakta dan informasi yang bersifat abstrak. Sehingga dirasakan oleh siswa menjadi mata pelajaran yang tidak disenangi, tidak menarik, dan menjemukan untuk dipelajari. Padahal pembelajaran yang berkaitan dengan ilmu pengetahuan alam sangat penting dikuasai siswa untuk dapat memanfaatkan alam yang ada di sekitarnya untuk kepentingan kehidupan siswa itu sendiri.

Dalam dokumen kurikulum 2006 (KTSP) dijelaskan "Hakekat pendidikan IPA adalah cara mencari tahu tentang faktafakta, konsep-konsep, dan prinsip-prinsip tentang alam semesta dan diri sendiri untuk kehidupan.

Dari uraian di atas begitu pentingnya pembelajaran Ilmu Pengetahuan Alam bagi siswa, terutama bagi dirinya sendiri dan bagi kehidupannya kelak di masyarakat. Benarkah pembelajaran Ilmu Pengetahuan Alam (IPA) merupakan suatu pembelajaran yang sukar dan membosankan? Jika dikaji secara mendalam tidaklah demikian, karena apabila disajikan secara menarik, kreatif, dan dinamis siswa akan menyukainya.

Desain pembelajaran yang dibuat diwujudkan dalam kegiatan interaksi kegiatan belajar mengajar di dalam kelas. Pada akhirnya, kegiatan program yang telah dilaksanakan itu dinilai atau dievaluasi; salah satunya melalui keberhasilan yang ditunjukan oleh prestasi dalam belajar peserta didik. Penilaian ini dimaksudkan untuk mengetahui keberhasilan proses pembelajaran serta sebagai bahan tindak lajut untuk perbaikan penyusunan desain pembelajaran selanjutnya.

Berdasarkan hasil pembelajaran, guru dapat mengetahui sejauh mana hasil belajar siswa dihubungkan dengan efektifitas program pembelajaran, khususnya dalam 
materi bagian-bagian utama tubuh hewan dan kegunaannya. Dengan kata lain keberhasilan siswa sangat dipengaruhi oleh kualitas program pembelajaran.

Menurut pengakuan sesama rekan seprofesi dan berdasarkan pengalaman sendiri dalam melaksanakan pembelajaran di kelas II Sekolah Dasar sulit untuk menekankan pemahaman siswa, banyak peserta didik yang tidak dapat mengikuti pembelajaran, acuh tak acuh terhadap materi, ngobrol dengan teman. Pada dasarnya proses pembelajaran kurang kondusif walaupun sudah diskenariokan sedemikian rupa. Maka hasil belajarnya pun tidak baik. Terutama pada materi pembelajaran bagian-bagian utama tubuh hewan dan kegunaannya. Rata-rata hasil ulangan siswa mencapai KKM dan diharapkan yaitu 68. Padahal kriteria ketuntasan minimal pada materi ini ditetapkan di sekolah yaitu 75. Sedangkan hasil belajar siswa pada pembelajaran IPA, peneliti melaksanakan perbaikan pembelajaran melalui kegiatan Penelitian Tindakan Kelas (PTK).

Berdasarkan urain di atas, penulis tertarik untuk melakukan Penelitian Tindakan Kelas berbentuk perbaikan pembelajaran tentang "Penggunaan Pendekatan Kontekstual untuk Meningkatkan Hasil Belajar Siswa pada Materi Bagian-bagian Utama Tubuh Hewan dan Kegunaannya di Kelas II SDN Kulur I Kecamatan Majalengka Kabupaten Majalengka".

\section{KAJIAN PUSTAKA}

Menurut realita yang terjadi di sekolah, pada umumnya pembelajaran yang dilaksanakan berorientasi pada target penguasaan sejumlah materi. Peserta didik hanya dijejali dengan menghafal sejumlah fakta atau informasi yang disampikan guru. Dengan kegiatan tersebut peserta didik terbukti berhasil dalam kompetisi mengingat dalam waktu singkat atau jangka pendek, tetapi gagal dalam membekali peserta didik, untuk memecahkan persoalan dalam kehidupan jangka panjang.

Untuk mengatasi persoalan tersebut di atas, Nurhadi (2001:1) yang menyatakan bahwa dewasa ini ada kecenderungan untuk kembali pada pemikiran bahwa anak belajar lebih baik jika lingkungan diciptakan secara alamiah. Maksudnya, belajar akan lebih bermakna jika anak mengalami sendiri apa yang dipelajarinya bukan sekedar mengetahuinya.

Mengacu pada pendapat di atas, maka pendekatan kontekstual menjadi salah satu alternatif yang harus diterapkan dalam proses pembelajaran. Melalui pendekatan ini proses pembelajaran berlangsung secara alamiah dalam kegiatan siswa yang senantiasa bekerja dan mengalami sendiri. Siswa tidak hanya mentransfer pengetahuan yang datang dari guru. Siswa akan sadar bahwa yang dia pelajari akan berguna bagi kehidupannya nanti. Dengan kata lain, siswa akan memposisikan sebagai diri sendiri yang memerlukan suatu bekal untuk hidupnya nanti. Sebab mereka mempelajari apa yang bermanfaat bagi dirinya dan berupaya menggapainya. Melalui penerapan pendekatan ini strategi pembelajaran lebih dipentingkan daripada hasil.

Dalam pendekatan kontekstual (CTL) tugas guru adalah mengelola kelas sebagai sebuah tim yang bekerja bersama untuk menemukan sesuatu yang baru bagi anggota kelas (siswa). Sesuatu yang baru yakni pengetahuan dan keterampilan diperoleh dengan cara menemukan sendiri bukan diperoleh dari guru. Guru hanya mengatur strategi belajar, membantu menghubungkan pengetahuan lama dan baru, dan memfasilitasi belajar. Guru harus melupakan tradisi lama yakni guru akting di panggung siswa menonton, ubah siswa aktif bekerja dan belajar di panggung guru mengarahkan dari dekat.

Menurut Nurhadi (2001:1) yang dimaksud dengan pendekatan kontekstual (Contextual Teaching and Learning) yaitu, 
"Konsep belajar yang membantu guru mengaitkan antara materi yang diajarkan dengan situasi dunia nyata dan mendorong siswa membuat hubungan antara pengetahuan yang dimilikinya dengan penerapannya dalam kehidupan mereka sebagai anggota keluarga dan masyarakat"

Kemudian juga menurut Nurhadi (2001:5) yang dimaksud dengan pembelajaran kontekstual (Contextual Teaching and Learning) adalah : "Konsep belajar yang membantu guru mengaitkan antara materi yang diajarkannya dengan situasi dunia nyata siswa dan mendorong siswa membuat hubungan antara pengetahuan yang dimilikinya dengan penerapannya dalam kehidupan mereka sehari-hari, dengan melibatkan tujuh komponen utama pembelajaran efektif, yakni : kontruktivisme (Contructivision), bertanya (Question), menemukan (Inquiry), masyarakat belajar (Learning Community), pemodelan (Modeling), dan penilaian sebenarnya (Autentic assesment).

Sebuah kelas dikatakan menggunakan pendekatan CTL jika menerapkan ketujuh komponen tersebut dalam pembelajarannya. Penerapan CTL dalam kelas secara garis besar, langkahnya adalah sebagai berikut :

1) Kembangkan pemikiran bahwa anak akan belajar lebih bermakna dengan cara bekerja sendiri, menemukan sendiri, dan menginstruksikan sendiri pengetahuan dan keterampilan barunya.

2) Laksanakan sejauh mungkin kegiatan inkuiri untuk semua topik.

Dari uraian apar ahli di atas dapat disimpulkan bahwa pembelajaran konstektual adalah suatu kegiatan proses belajar yang mengutamakan kegiatan siswa yang lebih aktif, siswa lebih bermakna belajarnya, karena atas dasar kemauan sendiri tidak terpaksa. Siswa dijadikan subjek belajar, sedangkan guru hanya sebagai pengarah, pengawas kegiatan saja. Kegiatan belajar yang bersifat fleksibel membantu siswa lebih bergairah dan lebih bermakna.
Meningkatkan adalah "adanya perbedaan/perubahan dari keadaan awal menjadi lebih baik atau meningkat, sedangkan pemahaman kemampuan daya nalar menangkap sesuatu yang baru menjadi pengetahuan baru" (Purwanto, 1974 : 84).

Dalam bahasa Indonesia meningkat artinya membuat jadi lebih dari asalnya. Yang dimaksud hasil belajar adalah, "Perubahan di dalam kepribadian yang menyatakan diri sebagai pola baru dari pada reaksi yang berupa kecakapan, sikap, kebiasaan, kepandaian, atau suatu pengertian". (Wetherington, 1998).

Jadi menurut penulis yang dimaksud dengan meningkatkan hasil belajar di sini adalah suatu upaya seorang (guru) yang dilakukan untuk memberikan pengalaman pengetahuan pada siswa agar pengetahuan yang diberikan itu dikuasai atau dimiliki siswa. Sedangkan hasil belajar menurut penulis adalah sejumlah hasil pengalaman belajar siswa baik pengetahuan, keterampilan, maupun sikap yang diperoleh dari proses belajar itu sendiri.

\section{METODE PENELITIAN}

Kegiatan Penelitian ini dilaksanakan di kelas II Sekolah Dasar Negeri Kulur I UPTD Pendidikan Kecamatan Majalengka Kabupaten Majalengka dengan jumlah siswa 31 orang, yang terdiri dari 16 orang laki-laki dan 12 orang perempuan. Dalam penelitian ini dilakukan beberapa perbaikan pembelajaran yang dimulai kegiatannya dari tanggal 23 Oktober 2013 sampai dengan tanggal 30 Oktober 2013. Fokus perbaikan pembelajaran yang dilaksanakan yaitu pada mata pelajaran Ilmu Pengetahuan Alam (IPA) tentang bagian-bagian utama tubuh hewan dan kegunaannya.

Metode yang digunakan dalam penelitian ini adalah metode penelitian tindakan kelas (Class Action Research) yakni suatu bentuk penelitian yang bersifat reflektif dengan melakukan tindakan- 
tindakan tertentu agar dapat memperbaiki dan atau meningkatkan praktek-paraktek pembelajaran profesional.

Prosedur pelaksanaan perbaikan pembelajaran dengan metode penelitian tindakan kelas mengidentifikasi masalah yang dihadapi dalam pembelajaran yang direncanakan dua siklus. Adapun keefektifan tindakan yang dilakukan yaitu :

1. Perencanaan Awal
a. Merasakan adanya masalah.
b. Analisis masalah
c. Perumusan masalah

\section{Perencanaan Tindakan}

a. Membuat skenario pembelajaran.

b. Mempersiapkan fasilitas dan sarana pendukung yang diperlukan di kelas.

c. Mempersiapkan instrumen untuk merekam dan menganalisis data mengenai proses dan hasil tindakan.

d. Melaksanakan simulasi pelaksanaan tindakan perbaikan untuk menguji keterlaksanaan rancangan.

\section{Pelaksanaan Tindakan}

Pelaksanaan tindakan yang meliputi siapa yang melakukan apa, kapan, di mana, dan bagaimana melakukannya. Skenario tindakan yang telah direncakanan, dilaksanakan dalam situasi yang aktual. Pada saat yang bersamaan kegiatan ini juga disertai dengan kegiatan observasi dan interpretasi serta diikuti dengan kegiatan refleksi.

\section{Pengamatan}

Pada bagian pengamatan, dilakukan perekaman data yang meliputi proses dan hasil dari pelaksanan kegiatan. Tujuan dilakukannya pengamatan adalah untuk mengumpulkan bukti hasil tindakan agar dapat dievaluasi dan dijadikan landasan dalam melakukan refleksi.

\section{Refleksi}

Pada bagian refleksi dilakukan analisis data mengenai proses, masalah, dan hambatan yang dijumpai dan dilanjutkan dengan refleksi terhadap dampak pelaksanaan tindakan yang dilaksanakan.

\section{HASIL DAN PEMBAHASAN}

Data memegang peranan yang sangat penting dalam suatu penelitian. Sebab data yang diperoleh dapat dijadikan sebagai dasar kajian untuk menganalisis dan menarik kesimpulan dari suatu penelitian yang dilakukan oleh seseorang. Atau dengan kata lain data yang diperoleh akan mempengaruhi hasil tidaknya suatu penelitian yang dilakukan oleh seorang peneliti.

Data yang diperlukan dalam penelitian ini adalah hasil belajar. Untuk memperoleh data tersebut dilakukan dengan melaksanakan uji coba perbaikan pembelajaran menggunakan metode demontrasi pada pembelajaran bagianbagian utama tubuh hewan dan kegunaannya di kelas II SD Negeri Kulur I Kecamatan Majalengka Kabupaten Majalengka.

Pembelajaran yang dilakukan sebanyak dua kali atau dua siklus, dan diakhirir dengan pelaksanaan tes. Data yang dihasilkan dari dua kali tes itu adalah data kuantitatif yang berupa nilai tes akhir.

Selaian data kuantitatif dalam penelitian ini diperlukan juga data kualitatif, berupa kreatifitas siswa dalam pembelajaran, interaksi dengan siswa dalam pembelajaran, aktivitas guru dalam pembelajaran. Data ini akan diperoleh dari hasil observasi dengan alat pengumpul data berupa lembar observasi dan buku harian siswa. Kedua data tersebut kemudian dijadikan bahan pengolahan data dan analalisis data.

Setelah dilaksanakan uji coba perbaikan pembelajaran bagian-bagian utama tubuh hewan dan kegunaannya dengan menggunakan metode demontrasi diperoleh data hasil berupa nilai tes akhir 
(pos tes) dan data nilai kualitatif. Untuk pembelajaran IPA kelas II semester 2 nilai Kriteria Ketuntasan Minimal (KKM) adalah 75.

Setelah dilakukan tes awal ternyata banyak siswa yang belum mencapai KKM, di sini tercatat hanya 4 orang yang mendapat nilai di atas KKM, yang lain sebanyak 22 orang belum mencapai KKM, maka siswa tesebut dikatakan belum tuntas untuk materi tersebut. Hal tersebut tadi yang menyebabkan diadakan perbaikan pada siklus berikutnya.

Ketika sudah dilaksanakan siklus I maka diperoleh data yang di atas nilai KKM ada 12 orang dengan rata-rata 71,15 yang mendapat nlai di bawah KKM ada 14 orang. Maka persentase keberhasilan siswa yang mendapat nilai di atas nilai KKM 12 adalah $46,15 \%$.

Kemudian ketika sesudah dilakukan siklus II maka diperoleh hasil di atas KKM ada 21 orang dengan rata-rata 80,76 dan yang mendapat nilai di bawah KKM ada 5 orang sehingga persentase keberhasilan mencapai $80,76 \%$.

Dapat disimpulkan bahwa tingkat pemahaman siswa terhadap materi pembelajaran Ilmu Pengetahuan Alam khususnya tentang bagian-bagian utama tubuh hewan dan kegunaannya mengalami peningkatan.

Dari hasil pengolahan data dan sebagai hasil temuan serta refleksi dari permasalahan yang dijadikan fokus perbaikan pembelajaran tersebut dicapai karena adanya beberapa hal yang dilakukan sehingga menghasilkan peningkatan hasil yang memuaskan antara lain :

a. Pembelajaran dilaksanakan sesuai dengan yang direncanakan.

b. Menggunakan alat peraga yang kongkrit.

c. Penggunaan metode demontrasi yang dianggap sesuai materi yang diajarkan.
Akan tetapi walaupun sudah ada peningkatan hasil pembelajaran siklus I, masih terdapat siswa yang masih belum memahami materi pembelajaran karena dalam pelaksanaan diskusi dengan teman kelompok dan juga dalam kegiatan LKS masih main-main, tidak serius melakukan kegiatan tentang materi yang dibahas. Oleh karena itu perlu adanya perbaikan untuk siklus berikutnya. Untuk meningkatkan pemahaman siswa sekaligus meningkatkan hasil belajar siswa.

Pada siklus II, kegiatan pembelajaran dilaksanakan dengan materi masih melanjutkan tentang bagian-bagian utama tubuh hewan dan kegunaannya, dengan menggunakan metode demontrasi dengan kegiatan pengamatan, penelitian serta diskusi. Pembelajaran juga menggunakan alat peraga nyata berupa gambar bagian hewan sebagai obyek penelitian. Situasi belajar semakin aktif, siswa semakin termotivasi untuk belajar mengamati objek pembelajaran, sehingga siswa lebih memahami materi tentang bagian-bagian utama tubuh hewan dan kegunaannya. Dengan hasil tes pada siklus II mengalami peningkatan berarti perbaikan pembelajaran yang dilakukan pada siklus II melanjutkan hasil yang optimal.

Melalui refleksi pembahasan tentang hal-hal yang dilakukan guru dan siswa dalam proses perbaikan pembelajaran maka hasil yang diharapkan dalam proses perbaikan pembelajaran kemampuan siswa akan meningkat. Ini disebabkan telah dilakukan beberapa kegiatan, antara lain :

1. Proses pembelajaran dilaksanakan sesuai dengan apa yang telah direncanakan.

2. Penggunaan metode yang sesuai dengan materi pembelajaran yang disampaikan.

3. Penggunaan alat peraga yang kongkrit agar tidak terjadi verbalisme.

4. Pemberian kesempatan pada siswa seluas-luasnya serta motivasi yang terus menerus pada siswa.

5. Pemberian tes, tugas sebagai pendalaman latihan. 
Berdasarkan hasil dari siklus yang sudah dilakukan tersebut menunjukan adanya peningkatan hasil belajar siswa yaitu nilai tes siswa yang meningkat dari siklus I rata-rata 71,15 menjadi 80,76 pada siklus II, dan pencapaian siswa yang nilainya di atas KKM dari jumlah 13 orang pada siklus I sama menjadi 23 orang pada siklus II. Kemudian adanya peningkatan pesentase keberhasilan siswa dari $46,17 \%$ pada siklus I menjadi $80,76 \%$, termasuk tingkat keberhasilan tinggi, pada siklus II. Disimpulkan pendekatan kontekstual dapat meningkatkan hasil belajar siswa.

\section{SIMPULAN DAN SARAN}

\section{Simpulan}

Materi bagian-bagian utama tubuh hewan dan kegunaannya merupakan bagian dari Ilmu Pengetahuan Alam yang harus dikuasai siswa kelas II, karena tercantum dalam KTSP yang merupakan pedoman bagi guru. Untuk mengefektifkan pembelajaran bagian-bagian utama tubuh hewan dan kegunaannya diperlukan suatu pendekatan kontekstual yang memudahkan siswa memahami materi yang diajarkan. Dalam penelitian perbaikan pembelajaran ini penulis mencoba menggunakan pendekatan kontekstual, karena pendekatan kontekstual suatu pembelajaran yang mengaitkan materi pelajaran dengan situasi nyata siswa, baik asli mapun tiruan.

Keberhasilan pembelajaran bagianbagian utama tubuh hewan dan kegunaannya dengan menggunakan metode demonstrasi disebabkan pula oleh adanya keterlibatan siswa secara aktif dalam proses belajar mengajar. Setiap pendekatan pembelajaran tentu ada kelebihan dan kekurangannya. Penggunaan pendekatan pembelajaran yang digunakan tergantung situasi dan kondisi di lapangan.

\section{Saran Tindak Lanjut.}

Guru penting sekali untuk melakukan inovasi pembelajaran baik dengan melaksanakan penelitian tindakan kelas ataupun melaksanakan berbagai perbaikan pembelajarn untuk meningkatkan kualitas pembelajaran dan meningkatkan hasil belajar siswa sekaligus meningkatkan mutu pendidikan.

Siswa dapat memberikan penilaian kepada guru ketika dalam menyampaikan pembelajaran. Siswa dapat memberikan masukan kepada guru untuk perbaikan pembelajaran dalam rangka meningkatkan hasil belajar.

Dari proses kegiatan perbaikan pembelajaran ini pihak sekolah dapat dievaluasi mengenai kelengkapan (sarana prasarana pembelajaran) untuk mendukung keberhasilan peningkatan pembelajaran serta mutu pelajaran dan mutu pendidikan di sekolah tersebut.

Penulis berharap agar keberadaan

KKG, KKKS terus dijaga bahkan ditingkatkan frekuensi kegiatannya, sebab KKG dan KKKS adalah salah satu wadah kegiatan guru untuk menampung aspirasi segala hal tentang peningkatan mutu pembelajaran dan mutu pendidikan.

\section{DAFTAR PUSTAKA}

Azhar Muhamad lalu. 1993. Proses Belajar Mengajar Pola CBSA. Surabaya : Usaha Nasional

Depdikbud, 1989. Sistem Pendidikan Nasional. Jakarta : Balai Pustaka

Slamento. 1995. Belajar dan Faktor-faktor Yang Mempengaruhinya. Jakarta : Rineka Cipta.

Soelaeman. 1984. Menjadi Guru yang Baik. Bandung: Tarsito.

Soewarno. 1984. Menjadi Guru yang Baik. Bandung : Tarsito.

Syamsudin, Agin. 1984. Psikologi Pendidikan. Bandung : PT Remaja Rosdakarya

Usman, Moh. Uzer. 2000. Menjadi Guru Profesional. Bandung : Remaja Rosdakarya. 
Purwanto, Ngalim. 1990. Psikologi Pendidikan. Bandung: PT Remaja Rosdakarya

Ridwan, Saadah. 2000. Penelitian Tindakan Kelas Bagi Guru. Bandung: Dinas Pendidikan Jawa Barat

Riiyanto, Yatim 2009. Proses Belajar Mengajar di Sekolah. Jakarta : Kencana Prenada Media Group

Suryosubroto, 2009. Proses Belajar Mengajar di Sekolah. Jakarta: PT. Rineka Cipta

Undang. Gunawan. 1998. Peningkatan Mutu Proses Belajar Mengajar Sekolah Dasar. Bandung: CV Siger Tengah.

Sudirman, 1987. Ilmu Pendidikan. Bandung : PT Remaja Rosdakarya.

Azhar Mohamad 2000. Proses Belajar Mengajar Pola CBSA. Surabaya: Usaha Nasional

Yantos. 2000. Kamus Bahasa Indonesia Lengkap. Surabaya : Nidya Pustaka 